\title{
EFFECT OF SOME AMINO ACIDS ON TILLERING AND YIELD OF THREE BREAD WHEAT CULTIVARS
}

\author{
H. A. Baqir \\ Lecturer \\ M. A. S. Al-Naqeeb \\ Prof \\ Dept. of Field Crops - Coll. of Agric. Engin. Sci. -Univ. of Baghdad \\ haderabid@yahoo.com
}

\begin{abstract}
ABSTRSCT
The objective of this study was to investigate the effect of some amino acids on tillering and grain yield of bread wheat cultivars. A field experiment was carried out at the agricultural experiment station, College of Agriculture Engineering Sciences, University of Baghdad during the two winter seasons, 2016-2017 and 2017-2018. Randomized Complete Block Design within split plots arrangement was used in three replicates. The experiment included two factors, the first (main plots) was the wheat cultivars (IPA 99, Buhooth 22, and Abu-Graib3) and the second (sub-plots) was foliar application three amino acids (L-Tryptophan, L-Glycine, and L-Lysine) with concentrations 50 and $100 \mathrm{mg} \mathrm{L}^{-1}$ and the amino acid L-Cystine at 100 and $150 \mathrm{mg} \mathrm{L}^{-1}$ and control treatment. The treatments of foliar application were applied during two growth stages, the first was when the main stem had three leaves (ZGS: 13) and the second was when the plant entered the flowering stage (ZGS: 60). Results showed the significant superiority of Buhooth 22 in most growth traits, which produced the highest number of tillers.m ${ }^{-2}$ (556.30 and 568.15 tillers $\mathrm{m}^{-2}$ ), number of spikes (476.74 and 494.19 spikes $\left.\mathrm{m}^{-2}\right)$, weight of 1000 grains $(31.09$ and $32.43 \mathrm{~g}$ ), and grain yield (5.39 and $5.15 \mathrm{Mg} \mathrm{ha}^{-1}$ ) for the two seasons respectively. The treatment of foliar application L-Tryptophan at $50 \mathrm{mg} \mathrm{L}^{-1}$ was significantly superior in most traits of yield components which produced the highest values of the number of tillers $\left(616.89\right.$ and 627.78 tillers $\left.\mathrm{m}^{-2}\right)$, number of spikes $(477.00$ and 944.67 spikes $\left.\mathrm{m}^{-2}\right)$, weight of 1000 grains $(32.01$ and $33.55 \mathrm{~g})$, and grain yield $\left(5.77\right.$ and $\left.5.33 \mathrm{Mg} \mathrm{ha}^{-1}\right)$ in the two seasons, respectively. The response of wheat cultivar growth and yield to amino acids differed significantly.
\end{abstract}

Key words: number of tillers $\mathrm{m}^{-2}$, number of spikes $\mathrm{m}^{-2}$, weight of 1000 grains and grain yield.

Part of Ph.D. Dissertation of the first author

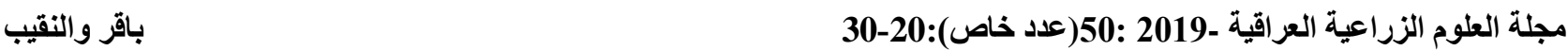

تأثير بعض الأحماض الأمينية في صفة التفريع والحاصل ومكوناته لثلاثة أصناف من حنطة الخبز

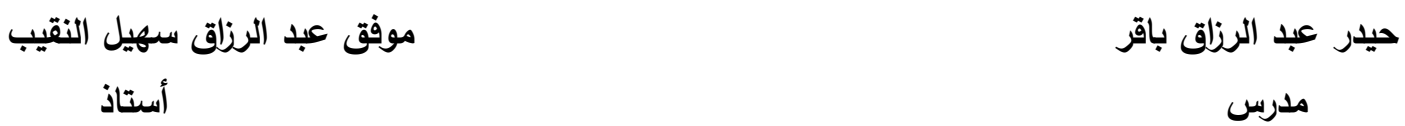

قسم المحاصيل الحقلية - كلية علوم الهندسة الزراعية - جامعة بغداد

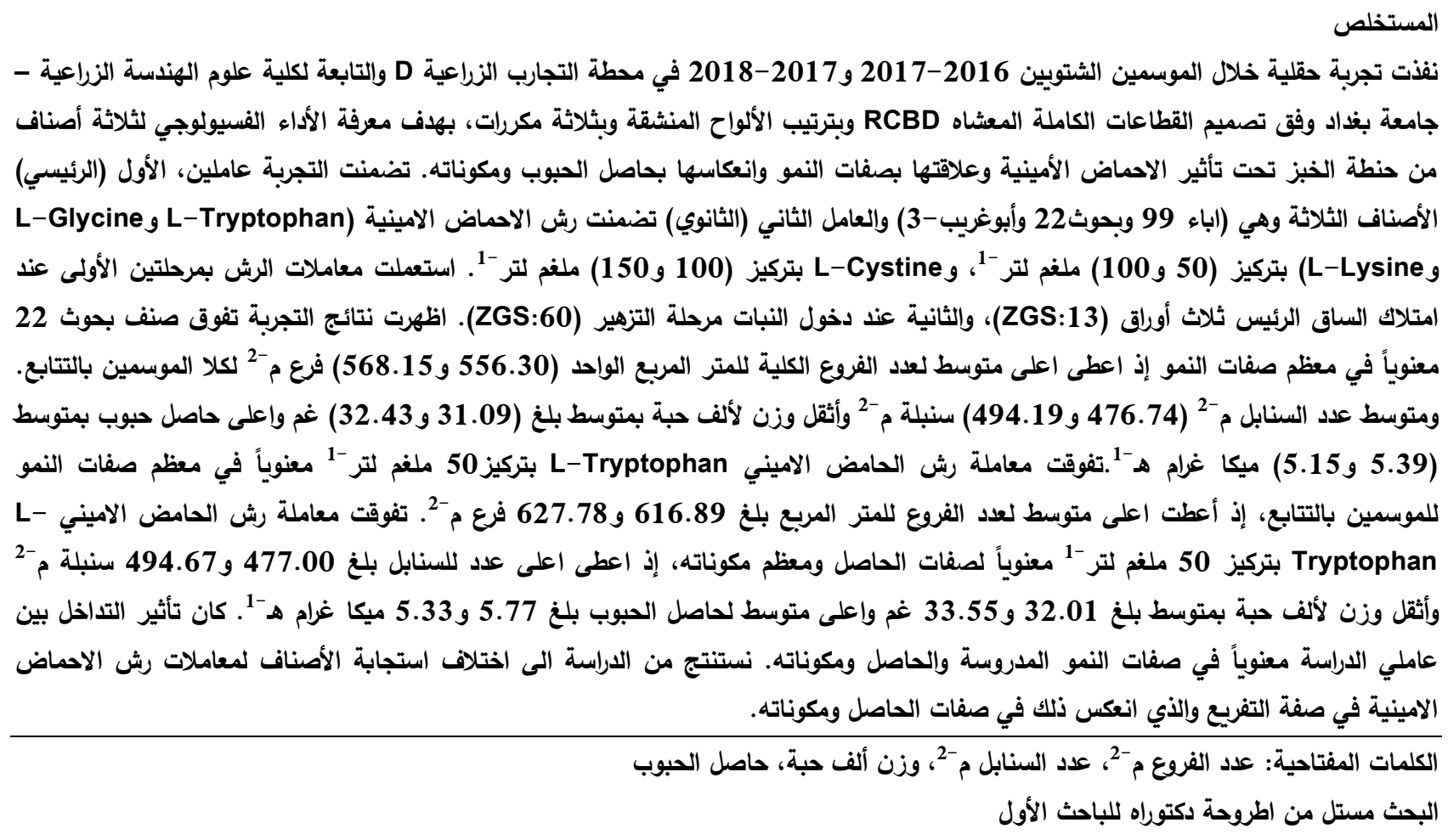

*Received:11/4/2018, Accepted:15/8/2018 


\section{INTRODUCTION}

Amino acids can have a positive effect on improving the growth and yield of wheat (Triticum eastivum L.) Production since foliar plants with amino acids plays a great role in stimulating physiological and biochemical processes. Tryptophan is one of the amino acids that activates the formation of natural auxins, playing a major role in stimulating the growth of roots in the plant; Moreover, Tryptophan is one of the most efficient physiological initiators and the main source of IAA in most living organisms $(25,27$, and 30). Amino acids have an important role in many biological processes, as a component of proteins. Their importance and effectiveness lie in all plant growth stages since they contribute to increasing the cell ability to absorb water and nutrients from soil and increase the vegetative growth Kandi etal (24). Referred that foliar application the wheat crop with amino acids under the fertilizer level of 166, 214, and $262 \mathrm{kgN} \cdot \mathrm{ha}^{-1}$ led to increasing plant height by $23.29 \%$ and chlorophyll content resulting in getting the highest degree of photosynthesis and increasing the grain yield (12). Foliar application Tryptophan with the concentrations of 25,50 and $100 \mathrm{mg} \mathrm{L}^{-1}$ after 30, 45, and 75 days from planting caused an increase in plant growth, The concentration of $25 \mathrm{mg} \mathrm{L}^{-1}$ produced the highest number of tillers (16). foliar application Cystine at $150 \mathrm{mg} .1^{-1}$ increased most traits of wheat when compared to the concentration of $100 \mathrm{mgL}^{-1}$. The results showed that foliar application of Tryptophan and Cystine at all concentrations caused significant increases in all wheat traits of compared to the control treatment. Nilesh et al (28) mentioned that biological regulators represented a group of chemicals, including
Cystine regulating plant physical and physiological activities. Many studies have carried out to investigate the effect of biological regulators on crop yield and quality. The results found by Zaboon et al (33) showed the significant differences between the two wheat cultivars (IPA 99 and Abu-Graib 3) in the number of tillers. $\mathrm{m}^{-2}$, where IPA 99 produced the highest value, 404.90 tillers $\mathrm{m}^{-2}$. The results found by AL- Hassan (5) showed that the Iraqi wheat cultivars (Iraq, Al-Fatih, Abu-Graib 3, and IPA95) were significantly differed in yield and yield components. The results of Abdulkarim (1) revealed differences among wheat cultivars in number of grains.spike $^{-1}$ and weight of 1000 grains, where Buhooth 22 produced the highest grain number, 59.83 grains.spike ${ }^{-1}$, while the cultivar, Hassad, recorded the highest weight of 1000 grains, $39.06 \mathrm{~g}$. This study aimed to invistigate the physiological behavior of three cultivars of bread wheat under the influence of different concentrations of four amino acids and their impacts to the characteristics of the crop growth, yield and yield components.

\section{MATERIALS AND METHODS}

Two field crops experiments were carried out at the fields of College of Agriculture Engineering Sciences, University of Baghdad, Jadriya, during the two winter seasons, 20162017 and 2017-2018 according to the randomized complete block design whith split plot arrangement in order to study the physiological behavior of three wheat cultivars (IPA, 99, Buhooth 22, and Abu-Graib3) under the effect of some amino acids. Soil samples were taken from the depths of $0-30 \mathrm{~cm}$ before planting to determine the chemical and physical characteristics of the soil (Table 1).

Table 1. Physical and chemical characteristics of the soil

\begin{tabular}{|c|ccc|}
\hline \multicolumn{2}{|c|}{ Characteristics } & Season 2016-2017 & Season 2017-2018 \\
\hline Soil structure & Sand & 496 & 502 \\
& Silt & 260 & 290 \\
Soil texture & Clay & 244 & 208 \\
Soil pH & Sandy loam & Sandy loam \\
EC $($ dS.m & -1) & 7.71 & 7.65 \\
Available Nitrogen mg.kg-1 & 2.80 & 2.30 \\
Available phosphor mg.kg-1 $^{-1}$ & 35.00 & 30.00 \\
Available Potassium mg.kg-1 & 10.20 & $\mathbf{8 . 2 2}$ \\
Organic matter \% & 165.00 & 151.00 \\
\hline
\end{tabular}


The experimental field was plowed twice in both seasons $(5 / 11 / 2016$ and $5 / 11 / 2017)$ then leveled and divided into 81 experimental units with dimensions $2 \times 2.5 \mathrm{~m}$. The study included two factors: first (main plots) wheat cultivars (IPA 99, Buhooth 22, and Abu-Graib 3) and the second (sub-plots) amino acids (50 and $100 \mathrm{mg} \mathrm{L}^{-1}$ of L-Tryptophan, 50 and $100 \mathrm{mg}$ $\mathrm{L}^{-1}$ of L-Glycine, 50 and $100 \mathrm{mg} \mathrm{L}^{-1}$ of LLysine, and 100 and $150 \mathrm{mg} \mathrm{L}^{1}$ of L- Cystine) in addition to the control treatment. Each experimental unit consisted of 12 rows with 2 $\mathrm{m}$ length and $0.2 \mathrm{~m}$ between therows. The treatments units were isolated from each other by $2 \mathrm{~m}$. Fields of two seasons were seeded on 23/11/2016 and 23/11/2017 using sowing rate120 kg ha-1. Two hundred $\mathrm{kg} \mathrm{Nha}^{-1}$ of Urea fertilizer $(46 \% \mathrm{~N})$ was added to the soil in three batches: the first, when the plants had three leaves unfolded (ZGS: 13), the second when the plant had two nodes on the main stem (ZGS: 32 ), and the third at initiation of booting stage (ZCS: 40) according to the Zadok's et al (32). Triple superphosphate $\left(46 \% \quad \mathrm{P}_{2} \mathrm{O}_{5}\right)$ with $100 \mathrm{~kg} \mathrm{ha}^{-1}$ was added at soil preparation. All crop and soil manage ments were carried out according to the recommendations of Jaddoa and Salih, (21). The experiment at field was irrigated when needed, an area of $0.3 \mathrm{~m} 2$ was harvested, and grain yield and its components were meajureal. The plants were harvested on $05 / 5 / 2017$ and $11 / 5 / 2018$ for the two seasons, respectively measuring the following: the average of the total number of tillers $\mathrm{m}^{-2}$, spike length $(\mathrm{cm})$, number of spikelets $\mathrm{Spike}^{-1}$, number spikes $\mathrm{m}^{-2}$, number grains $\mathrm{spike}^{-1}$, 1000 grain weight, and grain yield $\left(\mathrm{Mg} \cdot \mathrm{ha}^{-1}\right)$. The data were statistically analyzed, using the soft war Genstae, version 7, and the means were compared using the least significant differences (LSD) under the probability level of $5 \%$.

\section{RESULTS AND DECISION}

Number of tillers $\mathbf{~ m}^{-2}$ : The results in Table 2 showed significant differences among the cultivars and the foliar application treatments in this trait in both seasons. The plant of the cultivar Buhooth 22 were the superior, produced the highest averages (556.30 and 568.15 tillers $\mathrm{m}^{-2}$ ) in both seasons respectively, but did not significantly differed from the cultivar IPA 99, which produced 549.63 and
561.78 tillers $\mathrm{m}^{-2}$ in the two seasons respectively. This variation in the number of tillers among genotypes could be due to the genetic constitution. This results agreed with other researchers $(3,4,5,14,23$, and 33). Significant differences were revealed among amino acids treatments foliar application 50 $\mathrm{mg} \mathrm{ha}^{-1}$ of L-Tryptophan was superior to the other spraying treatments and producing the highest average of tillers number (616.89 and 627.78 tillers $\mathrm{m}^{-2}$ in both seasons respectively) and did not differed significantly from s foliar application L-Lysine at $50 \mathrm{mgL}^{-1}$, whereas the control treatment had the lowest averages of tiller number (431.44 and 445.11 tillers $\mathrm{m}^{-2}$ in the two seasons respectively). Table- 2 revered that foliar application amino acids LTryptophan and L-Lysine at the concentration of $50 \mathrm{mgL}^{-1}$ led to an increment in the number of tillers (by 11.91 and $3.11 \%$ ) and (by 11.15 and $4.33 \%$ ) compared to the treatments of foliar application L-Tryptophan and L-Lysine at $100 \mathrm{mg} . \mathrm{L}^{-1}$ in both seasons. These results were consistent with the finding of ElBassiouny (16) and El-Hosary et al (17). They referred to an increment in the number of tillers in wheat plants foliar application by the amino acid, Tryptophan with the concentration $50 \mathrm{mg} \mathrm{L}^{-1}$. Foliar application higher concentrations of L-Glycine and L-Cystine produced an increase in the percentage of the tiller number average (Table 4). Moreover, the same Table reveal that foliar application higher concentrations of L-Glycine and LCystine gave an increase in the percentage of the tiller number average (11.80 and $13.72 \%)$ in the first season and (11.55 and 13.50\%) in the second season compared to the lower concentrations of these amino acids. The increment gained in the number of tillers when sprayed with amino acids might be due to the huge role of amino acids in stimulating the physiological and biochemical processes which involved in protein constitution and carbohydrate synthesis through constructing chlorophyll and stimulating photosynthesis as well as encouraging the action of many enzymes, coenzymes, and bases of Purine and Puridine $(26,10,15,19)$. The superiority of LTryptophan at the concentration of $50 \mathrm{mgl}^{-1}$ might be attributed to the contribution of this amino acid in constructing IAA which in turn 
stimulated the cell division and expansion and thus the growth increment $(20,30,25)$. The interaction among cultivars and amino acids did not significant indicated that the response of cultivars in this experiment to amino acids was parallel in the number of tillers for both season

Table 2. Effect of amino acids and wheat cultivar on the number of tillers $\mathbf{~ m}^{-2}$ in the two seasons 2016-2017 and 2017-2018

\begin{tabular}{|c|c|c|c|c|}
\hline \multirow{3}{*}{ Amino acids } & \multicolumn{4}{|c|}{ Season 2016-2017 } \\
\hline & \multicolumn{4}{|c|}{ Cultivars } \\
\hline & Ibaa 99 & Buhooth 22 & Abu-Graib3 & Mean \\
\hline Control & 428.33 & 455.33 & 410.67 & 431.44 \\
\hline L-Tryptophan $50 \mathrm{mgl}^{-1}$ & 622.30 & 680.00 & 548.33 & 616.89 \\
\hline L-Tryptophan $100 \mathrm{mgl}^{-1}$ & 615.67 & 563.00 & 475.00 & 551.22 \\
\hline L-Glycine $50 \mathrm{mgl}^{-1}$ & 522.67 & 483.33 & 476.67 & 494.20 \\
\hline L-Glycine $100 \mathrm{mgl}^{-1}$ & 531.00 & 598.33 & 528.33 & 552.56 \\
\hline L-Lysine 50 mgl $^{-1}$ & 598.33 & 575.00 & 590.00 & 587.78 \\
\hline L-Lysine 100 mgl $^{-1}$ & 588.33 & 573.33 & 548.33 & $\mathbf{5 7 0 . 0 0}$ \\
\hline L- Cystine 100 mgl $^{-1}$ & 476.67 & 518.33 & 461.67 & 485.56 \\
\hline L- Cystine $150 \mathrm{mgl}^{-1}$ & 563.33 & 560.00 & 533.33 & 552.22 \\
\hline LSD 0.05 & NS & & & 43.73 \\
\hline & 549.63 & 556.30 & 508.04 & \\
\hline LSD 0.05 & 36.39 & & & \\
\hline \multirow[t]{2}{*}{ Amino acids } & \multicolumn{4}{|c|}{$\begin{array}{c}\text { Season 2017-2018 } \\
\text { Cultivars }\end{array}$} \\
\hline & Ibaa 99 & Buhooth 22 & Abu-Graib3 & Mean \\
\hline Control & 441.00 & 469.00 & 425.33 & 445.11 \\
\hline L-Tryptophan $50 \mathrm{mgl}^{-1}$ & 635.00 & 687.00 & 561.33 & 627.78 \\
\hline L-Tryptophan $100 \mathrm{mgl}^{-1}$ & 629.67 & 577.00 & 487.67 & 564.78 \\
\hline L-Glycine $50 \mathrm{mgl}^{-1}$ & 538.00 & 506.00 & 487.67 & 510.56 \\
\hline L-Glycine $100 \mathrm{mgl}^{-1}$ & 547.00 & 619.00 & 542.67 & 569.56 \\
\hline L-Lysine 50 mgl $^{-1}$ & 613.67 & 595.33 & 605.00 & 604.67 \\
\hline L-Lysine 100 mgl $^{-1}$ & 594.00 & 588.00 & 556.67 & 579.56 \\
\hline L- Cystine 100 mgl $^{-1}$ & 477.00 & 494.00 & 532.33 & 501.11 \\
\hline L- Cystine 150 mgl $^{-1}$ & 580.67 & 578.00 & 547.67 & 568.78 \\
\hline LSD 0.05 & NS & & & 43.78 \\
\hline $\begin{array}{c}\text { Mean } \\
\text { LSD 0.05 }\end{array}$ & $\begin{array}{l}561.78 \\
25.63\end{array}$ & 568.15 & $\mathbf{5 2 7 . 3 7}$ & \\
\hline
\end{tabular}

\section{Number of spikes $\mathbf{m}^{-2}$}

The results in Table 3 shows significant differences among cultivars and the treatments of foliar application with amino acids as well as the interaction between them. The cultivar, Buhooth 22 had the highest average of this trait in the two seasons (476.74 and 494.19 spike $\mathrm{m}^{-2}$ ) respectively, but did not differ significantly from IPA 99. The differences between IPA 99 and Abu-Graib 3 were not significantly. These results confirmed results of other studies such as $(5,14,22,23,33)$. The results in Table 5 illustrate the superiority of the treatment of foliar application $50 \mathrm{mg} \mathrm{L}^{-1}$ of L-Tryptophan with average $(477.00$ and 494.67 spikes $\mathrm{m}^{-2}$, namely an increment by 30.52 and $28.82 \%$ compared to the control treatment in two seasons respectively. This concentration did not differed significantly from foliar application $100 \mathrm{mgL}^{-1}$ of $\mathrm{L}$ -
Glycine, 50 or $100 \mathrm{mgL}^{-1}$ of L-Lysine, or 150 $\mathrm{mg} \mathrm{L}^{-1}$ of L-Cystine in the both seasons. This superiority could be due to the influence of this treatment for producing fertile tillers bearing spikes. This finding agreed with results of EL-Bassiouny (16), who found that the foliar application of Tryptophan caused increase in the number of spikes. The results in Table 5 indicate a significant interaction between studied factors indicating a difference in the response of cultivars to different amino acids and concentrations of amino acids for this trait. The amino acid, L-Tryptophan and L-Glycine with the concentrations (50 and 100 $\mathrm{mgl}^{-1}$ ) and the cultivars IPA 99, Buhooth 22, and Abu-Graib3, for instance, the number of spikes $\mathrm{m}^{-2}$ decreased by 8.64 and $7.47 \%$ of IPA 99 when the concentration of LTryptophan increased from 50 to $100 \mathrm{mg} \mathrm{l}^{-1}$, whereas, the number of spikes of the cultivar 
Buhooth 22, at the same treatment, decreased by 6.90 and $8.85 \%$, and for the cultivar AbuGraib 3, at the same concentration also, the decrease percentages were 6.06 and $7.47 \%$ in the two seasons respectively. There was another type of interaction, which was the differences in the of the Buhooth 22 and AbuGraib-3 compared to the cultivar IPA 99 when spraying the amino acid, L-Lysine, as well as between IPA 99 and Abu-Graib- 3 compared to Buhooth 22 when they were sprayed by LCystine, for example, the number of spikes $\mathrm{m}^{-2}$ of IPA 99 increased by 28.93 and $24.04 \%$ coincided with the increase in the concentration of spraying L-Cystine in the two seasons respectively.

Table 3. Effect of amino acids and wheat cultivar on the number of spikes $\mathbf{m}^{-2}$ in the two seasons 2016-2017 and 2017-2018

\begin{tabular}{|c|c|c|c|c|}
\hline \multirow{3}{*}{ Amino acids } & \multicolumn{4}{|c|}{ Season 2016-2017 } \\
\hline & \multicolumn{4}{|c|}{ Cultivars } \\
\hline & IPA 99 & Buhooth 22 & Abu-Graib3 & Mean \\
\hline Control & 383.67 & 401.67 & 311.00 & 365.44 \\
\hline L-Tryptophan 50 mgl $^{-1}$ & 493.33 & 531.00 & 406.67 & 477.00 \\
\hline L-Tryptophan $100 \mathrm{mgl}^{-1}$ & 450.67 & 494.33 & 382.00 & 442.33 \\
\hline L-Glycine $50 \mathrm{mgl}^{-1}$ & 462.67 & 445.33 & 460.33 & 456.11 \\
\hline L-Glycine $100 \mathrm{mgl}^{-1}$ & 477.67 & 469.67 & 472.00 & 473.11 \\
\hline L-Lysine 50 mgl $^{-1}$ & 439.33 & 505.67 & 418.00 & 454.33 \\
\hline L-Lysine 100 mgl $^{-1}$ & 486.33 & 494.33 & 373.00 & 451.22 \\
\hline L- Cystine 100 mgl $^{-1}$ & 399.67 & 482.00 & 341.33 & 407.67 \\
\hline L- Cystine 150 mgl $^{-1}$ & 515.33 & 466.67 & 439.00 & 473.67 \\
\hline LSD 0.05 & 73.79 & & & 35.80 \\
\hline $\begin{array}{c}\text { Mean } \\
\text { LSD 0.05 }\end{array}$ & $\begin{array}{l}456.52 \\
58.42\end{array}$ & 476.74 & 400.37 & \\
\hline \multirow[t]{2}{*}{ Amino acids } & \multicolumn{4}{|c|}{$\begin{array}{c}\text { Season 2017-2018 } \\
\text { Cultivars }\end{array}$} \\
\hline & IPA 99 & Buhooth 22 & Abu-Graib3 & Mean \\
\hline Control & 399.33 & 418.33 & 334.33 & 384.00 \\
\hline L-Tryptophan $50 \mathrm{mgl}^{-1}$ & 503.67 & 553.33 & 427.00 & 494.67 \\
\hline L-Tryptophan $100 \mathrm{mgl}^{-1}$ & 466.00 & 504.33 & 393.00 & 454.44 \\
\hline L-Glycine $50 \mathrm{mgl}^{-1}$ & 465.67 & 463.67 & 475.33 & 468.22 \\
\hline L-Glycine 100 mgl $^{-1}$ & 486.33 & 485.67 & 483.00 & 485.00 \\
\hline L-Lysine 50 mgl $^{-1}$ & 449.00 & 525.67 & 430.00 & 468.22 \\
\hline L-Lysine 100 mgl $^{-1}$ & 498.67 & 509.67 & 388.33 & 465.56 \\
\hline L- Cystine $100 \mathrm{mgl}^{-1}$ & 419.00 & 497.00 & 365.67 & 427.22 \\
\hline L- Cystine 150 mgl $^{-1}$ & 519.67 & 490.00 & 448.67 & 486.11 \\
\hline LSD 0.05 & 67.26 & & & 30.91 \\
\hline Mean & 467.48 & 494.19 & 416.15 & \\
\hline LSD 0.05 & 56.69 & & & \\
\hline
\end{tabular}

\section{Number of grains spike ${ }^{-1}$}

Results in Table 4 reveald a significant superiority of IPA 99, which produced the highest number of, grains averaged 63.37 and 61.45 grain spike ${ }^{-1}$ followed by Buhooth 22 with averages of 55.92 and 55.48 grains Spike 1 in both seasons respectively. The results indicated that IPA 99 differed significantly from Au-Graib-3 in this trait in both seasons. These results were agreed with results of other researchers $(5,14,7,23,22,1,33)$. foliar application amino acids showed a significant differences among the kind and concentrations of amino acids to this trait. foliar application L-Lysine at $100 \mathrm{mgl}^{-1}$ was superior in both seasons (59.89 and 59.05 grains spike ${ }^{-1}$ respectively, but did not differed significantly from spraying L-Tryptophan at $50 \mathrm{mgl}^{-1}$ in both seasons which produced averages of 59.43 and 57.89 grains spike ${ }^{-1}$ respectively, and from L-Glycine at $50 \mathrm{mg} \mathrm{L}^{-1}$ during the first season only when had an average of 59.04 grains Spike $^{-1}$. The control treatment produced the lowest number of grains in the two seasons (50.53 and 49.73 grains spike ${ }^{-1}$ ) with decline percentage of 15.62 and $15.78 \%$ when compared to the superior treatment respectively. The positive effect of amino acids on this trait may be due to their role in constructing DNA, RNA, and proteins needed to form the enzymes strongly needed for vital activity and for increasing the cell division that would lead to an increases in the flowering time. In addition to their role of 
stimulating the physiological processes at the flowering stage that would increase the pollen grain amount and eventually would reflex on the number of grains spike ${ }^{-1}$ could be occurred .It was showed from table 4 a significant differences among the amino acids when the different foliar application concentrations except for L-Cystine during the first season only. There was a significant effect of interaction between the two factors on this trait. This revealed that cultivars response differed in this trait due to difference kinds and concentrations of amino acids in both seasons.
The number of grains.spike ${ }^{-1}$ of the two cultivars, IPA 99 and Buhooth 22 decreased significantly when the concentration of LTryptophan and L-Glycine increased from 50 to $100 \mathrm{mgL}^{-1}$, whereas, the number of grains per spike of Abu-Graib 3 increased when the plants were foliar application by $100 \mathrm{mg} \mathrm{L}^{-1}$ of Tryptophan and L-Glycine also in both season. The Table 4 reveal that the increment of LCystine concentration led an increment in the number of grains of IPA 99 and Abu-Graib 3. While in the variety decreased Buhooth 22 in both season.

Table 4. Effect of amino acids and wheat cultivar on the number of grains Spike ${ }^{-1}$ in the two seasons 2016-2017 and 2017-2018

\begin{tabular}{|c|c|c|c|c|}
\hline \multirow{3}{*}{ Amino acids } & \multicolumn{4}{|c|}{ Season 2016-2017 } \\
\hline & \multicolumn{4}{|c|}{ Cultivars } \\
\hline & IPA 99 & Buhooth 22 & Abu-Graib3 & Mean \\
\hline Control & 55.10 & 49.55 & 46.93 & 50.53 \\
\hline L-Tryptophan $50 \mathrm{mgl}^{-1}$ & 68.36 & 56.14 & 53.80 & 59.43 \\
\hline L-Tryptophan $100 \mathrm{mgl}^{-1}$ & 58.06 & 57.77 & 55.40 & $\mathbf{5 7 . 0 8}$ \\
\hline L-Glycine $50 \mathrm{mgl}^{-1}$ & 66.39 & 58.58 & 52.16 & 59.04 \\
\hline L-Glycine $100 \mathrm{mgl}^{-1}$ & 62.09 & 52.59 & 55.00 & 56.56 \\
\hline L-Lysine $50 \mathrm{mgl}^{-1}$ & 62.16 & 59.57 & 51.93 & $\mathbf{5 7 . 8 9}$ \\
\hline L-Lysine $100 \mathrm{mgl}^{-1}$ & 65.02 & 64.38 & 50.27 & $\mathbf{5 9 . 8 9}$ \\
\hline L- Cystine 100 mgl $^{-1}$ & 65.75 & 54.37 & 51.46 & $\mathbf{5 7 . 1 9}$ \\
\hline L- Cystine 150 mgl $^{-1}$ & 67.40 & 50.33 & 55.89 & $\mathbf{5 7 . 8 7}$ \\
\hline LSD 0.05 & 2.30 & & & 1.27 \\
\hline $\begin{array}{c}\text { Mean } \\
\text { LSD 0.05 }\end{array}$ & $\begin{array}{l}63.37 \\
1.34\end{array}$ & 55.92 & 52.54 & \\
\hline \multirow[t]{2}{*}{ Amino acids } & \multicolumn{4}{|c|}{$\begin{array}{c}\text { Season 2017-2018 } \\
\text { Cultivars }\end{array}$} \\
\hline & IPA 99 & Buhooth 22 & Abu-Graib3 & Mean \\
\hline Control & 54.11 & 48.40 & 46.67 & 49.73 \\
\hline L-Tryptophan $50 \mathrm{mgl}^{-1}$ & 64.12 & 58.45 & 51.09 & $\mathbf{5 7 . 8 9}$ \\
\hline L-Tryptophan $100 \mathrm{mgl}^{-1}$ & 59.20 & 54.00 & 52.81 & 55.34 \\
\hline L-Glycine $50 \mathrm{mgl}^{-1}$ & 63.95 & 57.47 & 50.44 & $\mathbf{5 7 . 2 9}$ \\
\hline L-Glycine $100 \mathrm{mgl}^{-1}$ & 59.96 & 50.60 & 54.11 & 54.89 \\
\hline L-Lysine $50 \mathrm{mgl}^{-1}$ & 60.11 & 59.00 & 51.24 & 56.79 \\
\hline L-Lysine 100 mgl $^{-1}$ & 63.85 & 63.27 & 50.04 & 59.05 \\
\hline L- Cystine 100 mgl $^{-1}$ & 63.47 & 54.53 & 51.11 & 56.37 \\
\hline L-Cystine 150 mgl $^{-1}$ & 64.26 & $\mathbf{5 3 . 5 7}$ & 56.09 & $\mathbf{5 7 . 9 7}$ \\
\hline LSD 0.05 & 2.27 & & & 1.29 \\
\hline Mean & 61.45 & 55.48 & 51.51 & \\
\hline LSD 0.05 & 1.15 & & & \\
\hline
\end{tabular}

Weight of a thousand grains (g)

Grain weight is one of the yield components, which influence directly to the plant yield influenced by the duration of grain filling and its rate, which depend heavily upon genotypes and environmental conditions. The results in Table 5 shows a significant differences resulted from the effect of each of wheat cultivars, amino acids and interaction between them. Buhooth 22 produced the highest ges of this trait (31.09 and 32.43) in the first and second seasons respectively and it was differed significantly from the other two cultivars, IPA 99 and Abu-Graib 3 during the first season and only from Abu -Graib 3 during the second season. The results in the Table 5 show a significant differences between IPA 99 and Abu- Graib 3 in this trait in both seasons. This results was consistent with the results of other researchers $(3,22,23,33)$. Table 5 shows that foliar application L- 
Tryptophan at concentration of $50 \mathrm{mgL}^{-1}$ gave the heaviest weight of 1000 grains averaged 32.01 and $33.55 \mathrm{~g}$ in the two seasons respectively, but did not differed significantly from spraying L-Lysin at $50 \mathrm{mgL}^{-1}$ in the first season. Thus the treatment of foliar application L-Tryptophan at 50mg. $1^{-1}$ achieved an increments of 11.96 and $12.13 \%$ compared to the control which had the lowest weight of 1000 grains averaged 28.59 and $29.92 \mathrm{~g}$ in the two seasons respectively. foliar application LTryptophan at $50 \mathrm{mg} \mathrm{L}^{-1}$ resulted in a decrease in the number of grains spike ${ }^{-1}$ Compared to foliar application L-Lysine at the concentration of $100 \mathrm{mgL}^{-1}$ accompanied by an increase in the weight of 1000 grains, the phenomenon that might be due to lower competition for photosynthesis products, These results are consistent with the results of Azimi et al (13) who referred to that foliar application Tryptophan achieved an increase in grain weight by $7 \%$ compared to the control treatment. It was clear from Table7 that foliar application the same amino acid at the concentration of $100 \mathrm{mgL}^{-1}$ decreased the weight of 1000 grains. The effect of the interaction between the two factors was significant on the trait in both seasons indicating the differences in the cultivar response to amino acids application, thus the weight of 1000 grains of IPA 99 and Buhooth 22 decreased resulting from spraying each of L-Glycine and L-Cystin at $100 \mathrm{mg} . \mathrm{l}^{-1}$, while the grain weight of Abu-Graib 3 increased as a result of spraying L-Glycine at $100 \mathrm{mg} . \mathrm{l}^{-1}$, on the other hand, increasing the concentration of L-Tryptophan decreased the weight of 1000 grains of IPA 99 and Abu-Graib, while it increased the grain weight of Buhooth 22 in both seasons.

Table 5. Effect of amino acids and wheat cultivar on the weight of 1000 grains in the two season, 2016-2017 and 2017-2018

\begin{tabular}{|c|c|c|c|c|}
\hline \multirow{3}{*}{ Amino acids } & \multicolumn{4}{|c|}{ Season 2016-2017 } \\
\hline & \multicolumn{4}{|c|}{ Cultivars } \\
\hline & IPA 99 & Buhooth 22 & Abu-Graib3 & Mean \\
\hline Control & 29.54 & 28.31 & 27.91 & 28.59 \\
\hline L-Tryptophan $50 \mathrm{mgl}^{-1}$ & 34.03 & 32.38 & 29.61 & 32.01 \\
\hline L-Tryptophan $100 \mathrm{mgl}^{-1}$ & 31.39 & 35.46 & 28.29 & 31.71 \\
\hline L-Glycine $50 \mathrm{mgl}^{-1}$ & 30.45 & 33.68 & 30.12 & 31.41 \\
\hline L-Glycine $100 \mathrm{mgl}^{-1}$ & 29.96 & 30.47 & 31.32 & 30.58 \\
\hline L-Lysine $50 \mathrm{mgl}^{-1}$ & 29.84 & 32.73 & 32.27 & 31.61 \\
\hline L-Lysine $100 \mathrm{mgl}^{-1}$ & 29.83 & 28.55 & 29.37 & 29.25 \\
\hline L- Cystine $100 \mathrm{mgl}^{-1}$ & 30.73 & 28.55 & 29.75 & 29.67 \\
\hline L- Cystine 150 mgl $^{-1}$ & 30.82 & 29.69 & 31.74 & 30.75 \\
\hline LSD 0.05 & 0.74 & & & 0.43 \\
\hline $\begin{array}{c}\text { Mean } \\
\text { LSD 0.05 }\end{array}$ & $\begin{array}{l}30.73 \\
0.31\end{array}$ & 31.09 & 30.04 & \\
\hline \multirow[t]{2}{*}{ Amino acids } & \multicolumn{4}{|c|}{$\begin{array}{l}\text { Season 2017-2018 } \\
\text { Cultivars }\end{array}$} \\
\hline & IPA 99 & Buhooth 22 & Abu-Graib3 & Mean \\
\hline Control & 30.81 & 29.66 & 29.29 & 29.92 \\
\hline L-Tryptophan $50 \mathrm{mgl}^{-1}$ & 35.46 & 34.24 & 30.95 & 33.55 \\
\hline L-Tryptophan $100 \mathrm{mgl}^{-1}$ & 32.74 & 36.08 & 29.84 & 32.89 \\
\hline L-Glycine $50 \mathrm{mgl}^{-1}$ & 32.04 & 34.52 & 31.58 & 32.71 \\
\hline L-Glycine $100 \mathrm{mgl}^{-1}$ & 31.28 & 32.43 & 32.81 & 32.18 \\
\hline L-Lysine 50 mgl $^{-1}$ & 31.65 & 33.69 & 33.28 & 32.88 \\
\hline L-Lysine 100 mgl $^{-1}$ & 31.54 & 30.11 & 30.90 & 30.85 \\
\hline L-Cystine $100 \mathrm{mgl}^{-1}$ & 32.48 & 30.09 & 31.53 & 31.37 \\
\hline L-Cystine 150 mgl $^{-1}$ & 32.58 & 31.01 & 33.56 & 32.38 \\
\hline LSD 0.05 & 1.04 & & & 0.60 \\
\hline Mean & 32.29 & 32.43 & 31.53 & \\
\hline LSD 0.05 & $\mathbf{0 . 5 0}$ & & & \\
\hline
\end{tabular}


Grain yield ( $\left.\mathrm{Mg} \mathrm{ha}^{-1}\right)$

Grain yield is considered accumulation of its component, such as the number of spikes area unit $^{-1}$, umber of grain.spike ${ }^{-1}$, and weight of 1000 grains. It is determined by the ability of source to supply the nutrients on one hand and by the sink capacity to store these nutrients on the other. Some of them are related to the genetic factors and the others to the environmental influences. Results in Table 6 shows a significant differences among cultivars, due to foliar application amino acids. Buhooth 22 produced the highest yield (5.39 and $5.15 \mathrm{Mg} \mathrm{ha}^{-1}$ ) at first and second seasons, respectively. but did not differed significantly from IPA 99. Buhooth 22, recorded an increases in grain yield by 20.04 and $19.21 \%$ compared to Abu- Graib 3 which gave the lowest yield of grains averaged 4.49 and 4.32 $\mathrm{Mg} \mathrm{ha}^{-1}$ for both seasons. Results also showed that the differences between IPA 99 and AbuGraib 3 was not significant in this trait in both seasons. The reason of the superiority of Buhooth 22 can be due to its superiority in the number of tillers (Table 2), number of spikes (Table 3), and weight of 1000 grains (Table 5), These results are consistent with the results of Kadom, (23) who found that Buhooth 22 produced the highest grain yield (5.46 and $5.14 \mathrm{Mg} \mathrm{ha}^{-1}$ ) in the two seasons respectively, but did not differed significantly from IPA 99 in both seasons. The treatment of foliar application L-Tryptophan at $50 \mathrm{mgL}^{-1}$ was significantly superior in the two seasons (5.77 and 5.33 Mg.ha ${ }^{-1}$ ) (Table 6), with an increment 47.57 and $42.13 \%$ compared to the control which produced the lowest averages (3.91 and $\left.3.75 \% \mathrm{Mg} \mathrm{ha}^{-1}\right)$. Results in the same Table shows that foliar application L-Tryptophan at $50 \mathrm{mgL}^{-1}$ did not differed significantly from other two treatments of L-Lysine at $50 \mathrm{mgL}^{-1}$ or L-Cystine at $150 \mathrm{mgL}^{-1}$ in for both Seasons. Results of Table 8 showed that the differences in the grain yield produced from foliar application different concentrations of the amino acids were not significant except of LTryptophan, where increasing the amino acid concentration caused a decline in grain yield except L-Cystin in both seasons. When the concentrations of L-Tryptophan, L-Glycine, and Lysine increased the grain yield in both seasons decreased by (17.50 and 13.13\%), (1.82 and $1.23 \%)$, and (7.98 and $0.39 \%)$ respectively. The grain yield increased by $7.50 \%$ and $7.43 \%$ in the two seasons respectively, when the L-Cystine concentration increased to $150 \mathrm{mg} \mathrm{l}^{-1}$. The reason of the increased of grain yield resulted from spraying L-Tryptophan could be due to increasing the number of tillers (Table 2) leading to an increment in the weight of 1000 grains (Table 5), as well as its contribution to the level increment of IAA, GA3, and interior cytokinnens in the plants, leading to improve growth and yield. This result consisted with results of EL-Bassiouny (16), who found that the treatment of foliar application Tryptophan at $50 \mathrm{mgL}^{-1}$ achieved the highest average of grain yield, and Nilesh et al (28) who reported that foliar application wheat plants with highest doses of L-Cystine produced highest grain yield. Low doses, did not show significant differences. Aldesuquyet al (8) revealed that sparing Glycinebetaine affected positively on the yield and its components. A significant interaction was found among cultivars and amino acids concentrations in grain yield. This showed that the response of wheat cultivars differed due to amino acids concentrations. There was an increases in the grain yield of IPA 99 accompanied by increasing the concentrations of L-Glycine and L-Cystine sprayed, in the contrast to Buhooth 22. The grain yield of Abu-Graib increased in both seasons when the concentration of LCystine increased, while the increment was limited in the second season when L-Glycine was used. Table 8 showed that the highest response percentage was $64.67 \%$, compared to the control in the first season, due to application of Buhooth 22 with $50 \mathrm{mg} \mathrm{l}^{-1}$ of Tryptophan, while IPA 99 recorded the highest response percentage $49.46 \%$ at application of $50 \mathrm{mgL}^{-1}$ of Tryptophan Compared to the control treatment in the second season. 
Table 6. Effect of amino acids and wheat cultivar on the grain yield $\left(\mathrm{Mg} \mathrm{ha}^{-1}\right)$ in the two season, 2016-2017 and 2017-2018

\begin{tabular}{|c|c|c|c|c|}
\hline \multirow{3}{*}{ Amino acids } & \multicolumn{4}{|c|}{ Season 2016-2017 } \\
\hline & \multicolumn{4}{|c|}{ Cultivars } \\
\hline & Ibaa 99 & Buhooth 22 & Abu-Graib3 & Mean \\
\hline Control & 3.84 & 4.19 & 3.71 & 3.91 \\
\hline L-Tryptophan $50 \mathrm{mgl}^{-1}$ & 5.69 & 6.90 & 4.71 & 5.77 \\
\hline L-Tryptophan $100 \mathrm{mgl}^{-1}$ & 5.26 & 4.73 & 4.30 & 4.76 \\
\hline L-Glycine $50 \mathrm{mgl}^{-1}$ & 4.06 & 5.98 & 4.79 & 4.94 \\
\hline L-Glycine $100 \mathrm{mgl}^{-1}$ & 5.05 & 4.90 & 4.61 & 4.85 \\
\hline L-Lysine 50 mgl $^{-1}$ & 5.81 & 6.11 & 4.62 & 5.51 \\
\hline L-Lysine 100 mgl $^{-1}$ & 5.66 & 5.02 & 4.53 & 5.07 \\
\hline L- Cystine 100 mgl $^{-1}$ & 4.55 & 5.81 & 4.04 & 4.80 \\
\hline L- Cystine $150 \mathrm{mgl}^{-1}$ & $\mathbf{5 . 5 0}$ & 4.87 & 5.13 & 5.16 \\
\hline LSD 0.05 & 1.10 & & & 0.62 \\
\hline $\begin{array}{c}\text { Mean } \\
\text { LSD 0.05 }\end{array}$ & $\begin{array}{l}5.05 \\
0.58\end{array}$ & 5.39 & 4.49 & \\
\hline \multirow[t]{2}{*}{ Amino acids } & \multicolumn{4}{|c|}{$\begin{array}{c}\text { Season 2017-2018 } \\
\text { Cultivars }\end{array}$} \\
\hline & Ibaa 99 & Buhooth 22 & Abu-Graib3 & Mean \\
\hline Control & 3.74 & 4.06 & 3.46 & 29.92 \\
\hline L-Tryptophan $50 \mathrm{mgl}^{-1}$ & 5.59 & 5.98 & 4.44 & 33.55 \\
\hline L-Tryptophan $100 \mathrm{mgl}^{-1}$ & 5.13 & 4.59 & 4.16 & 32.89 \\
\hline L-Glycine $50 \mathrm{mgl}^{-1}$ & 4.01 & 5.89 & 4.63 & 32.71 \\
\hline L-Glycine $100 \mathrm{mgl}^{-1}$ & 4.94 & 4.69 & 4.72 & 32.18 \\
\hline L-Lysine 50 mgl $^{-1}$ & 5.25 & 5.52 & 4.44 & 32.88 \\
\hline L-Lysine 100 mgl $^{-1}$ & 5.51 & 5.26 & 4.40 & 30.85 \\
\hline L- Cystine 100 mgl $^{-1}$ & 4.40 & 5.64 & 3.69 & 31.37 \\
\hline L- Cystine 150 mgl $^{-1}$ & 5.02 & 4.76 & 4.96 & 32.38 \\
\hline LSD 0.05 & 0.96 & & & 0.52 \\
\hline Mean & 4.84 & 5.15 & 4.32 & \\
\hline LSD 0.05 & 0.57 & & & \\
\hline
\end{tabular}

\section{REFERENCES}

1. Abdulkarim, P.H.A.2017.Phenotype and Distinguish Study for Varieties of Bread Wheat (Treaticum aestivum L.) In Northern Region Condition of Iraq. M.Sc.Thesis. College. Agric. Univ. of Kirkuk .pp:87

2. Akram, M.2011. Growing and yield components of wheat under water stress of different growth stages. Bangladesh J. Agric. Res., 36(3):455-468

3. Al- Amiri, M. M. A. S. 2016. Evaluating Several Wheat and Triticale Genotypes under the Condition of Rainfed -Farming in Sulaymaniyah Governorate. M.Sc. Thesis, Dept. of Field Crop. College of Agriculture, University of Anbar. pp: 111

4. AL- Hassan, M. F.H.2007. Tillering Pattern and Capacity of Five Wheat Cultivars (Triticum aestivum L.) as Influenced by Sowing Date and its Relationship to Grain Yield and Its Components M.Sc. Dept. of Field Crops, College of Agriculture, University of Bagdad .pp:153
5. AL- Hassan, M. F.H. 2011. Understanding of Tillering In Different Wheat Cultivars As Influenced By Seeding Rate And Nitrogen Levels And Its Relationship To Grain Yield And Its Components. Ph.D. Dissertation. College of Agriculture. Univ. of Baghdad. pp: 143

6. Al- maemuri, S.K.A.2017. Effect of Sillicon on Growth and Yield of Some Wheat Genotypes Cultivated in Saline Soil. M.Sc.Thesis. College of Agric. Univ. of AlQasim Green. pp: 103

7. Al-Dawoodi, S. A. M and D. S. M., AlObaidi. 2014. Estimation of some of the genetic markers and path analysis of quantitative and qualitative characteristics in the genotypes of wheat (Triticum aestivum L.) Journal of Tikrit University for Agriculture Sciences. 14 (1): 87-102

8. Aldesuquy, S. H, M. A. Abbas, S. A. AboHamed, A. H. Elhakem and S. S. Alsokari. 2012. Glycine betaine and salicylic acid induced modification in productivity of two different cultivars of wheat grown under water 
stress. Journal of Stress Physiology and Biochemistry 8(2): 72-89

9. Al-Namrawi, S.K.H. 2014. Effect of some Triticum aestivum L. Cultivars Grown in Gypsum Soils on Growth, Yield and Physiochemical Characteristics of Grains. M.Sc.Thesis Dept. of Field Crops, College of Agriculture, University of Tikrit, pp: 119

10. Al-Said, M.A. and A.M. Kamal. 2008. Effect of folair spray with folic acid and some amino acids on flowering yield and quality of sweet pepper. J. Agric. Sci. Mansoura Univ., 33(10): $7403-7412$

11. Al-Tahir, F. M. M. and I. R. S. Al Hamdaoui. 2016. The contribution of the flag leaf and the lower parts of the leaves and spike in the production of dry matter and composition holds the grain for three Wheat. AL - Muthanna Journal of Agricultural Sciences, 4 ( 2): 13 -19

12. Ashoori, M., M. Esfehani, S. Abdollahi and B. Rabiei.2013. Effects of organic fertilizer complements application on grain yield, nitrogen use efficiency and milling properties in two rice cultivars (Oryza sativa L.). Iranian J. Field Crop Sci., 43: 701-713

13. Azimi, M.S., J. Daneshian, S. Sayfzadeh and S. Zare.2013. Evaluation of amino acid and Salicylic acid application on yield and growth of wheat under water deficit. Intl $\mathbf{J}$ Agri Crop Sci. 5 (8): 816-819

14. Baqir, H.A.A.2011.Relationship between Sowing Depth, Coleoptile Length, Field Emergence and Yield of Six Wheat Cultivars. M.Sc.Thesis. College. Agric. Univ. of Baghdad. pp: 113

15. El- Ghamry, M, K. M. Abd El- Hai and M. Ghoneem. 2009. Amino and humic acids promote growth, yield and disease resistance of Faba Bean cultivated in clayey soil. Aust. J. of Basic and Appl. Sci, 3(2): 731-739

16. EL- Bassiouny, H. M. S. 2005. Physiological responses of wheat to salinity alleviation by nicotinamide and tryptophan. Int. J. Agric. Biol., 7(4): 653-659

17. El-Hosary; A. A. G.Y. Hammam; A. ElMorsi; E.A. Hassan; M.E. El-Awadi and Y. R. Abdel-Baky.2013.Effect of some bioregulators on growth and yield of some wheat varieties under newly cultivated land conditions. New York Sci .J. 6(6).310-334
18. El-Naggar, E.M. and A.M. ElGhamry.2007. Effect of bio and chemical nitrogen fertilizers with foliar of humic and amino acids on wheat. J. Agric. Sci. Mansoura Univ., 32 (5): 4029-4043

19. Francessco, M. and M.Michele. 2009. Organic Fertilization as Resource for a Sustainable Agriculture.In L.R. Elswarth and W.O. Paly (Eds) Fertilizers: Properties, Application and Effects. Nova Science Bublishers, Inc.pp:417

20. Frankenberger, W.T.Jr., A.C. Chang and M. Arshad. 1990. Response of Raphanus sativus to the auxin precursor, L-tryptophan applied to soil. Plant Soil, 129: 235-41

21. Jaddoa, K. A. and H. M. Salih. 2013. Fertilization of Wheat Crop. Ministry of Agriculture. Guidance Bulletin-2. pp.12

22. Jaddoa, K.A., N.H. Zeboon and H.A.A. Baqer.2017. Effect of Tillers Removal and nitrogen levels on some growth traits of two bread wheat varieties. The Iraqi. J.Agric.Sci. 48(1): 274-284

23. Kadom, M.N. 2015.Effect Of Regulation of Source - Sink Relationship on The Accumulation of Assimilates and Grain Filing of Some Bread Wheat Cultivars Ph.D.

Dissertation Coll. of Agric., Univ. of Baghdad. pp: 132

24. Kandi, A. A.; A. E.M. Sharief; S.E. Seadh and D. S. K. Altai. 2016. Role of humic acid and amino acids in limiting loss of nitrogen fertilizer and increasing productivity of some wheat cultivars grown under newly reclaimed sandy soil .Int. J. Adv. Res. Biol. Sci. 3(4): 123-136

25. Kandil, E. E. and E. A. O. Marie .2017. Response of Some Wheat Cultivars to nano- , mineral fertilizers and amino acids foliar application Alexandria Science Exchange J. 38(1): 53-68

26. Khalil, A.A; E.A.M., Osman and F.A.A.Zahran.2008. Effect of amino acids and micronutrients foliar application on growth, yield and its components and chemical characteristics. J. Agric. Sci. Mansoura Univ., 33(4):3143-3150

27. Muhammad, K., Z.A. Zahir, A. Waseem and M.Arshad.1999. Azotobacter and Ltryptophan application for improving wheat yield. pakistan Journal of Biological Sci,(3):739-742 
28. Nilesh, G., P .Chakrborti, A. K. Rai, and P. C. Gupta. 2012. Effect of plant growth regulator on growth response and yield component in wheat (Triticum aestivum L.) Crop Res. J .of Agric/ Sci.3 (1): 204-208

29. Nur, D.; G. Selcuk and T. Yuksel. 2006. Effect of orgnic manure application and solariziation of soil microbial biomass and enzme activities under greenhouse conditions. Biol. Agric. Hortic. 3:305-320

30. Ramaih, S., M. Guedira and G.M. Paulsen. 2003. Relationship of indoleacetic acid and tryptophan dormancy and preharvest sprouting of wheat. Funct. Plant Biol., 30: 939-45
31. Sharma-Natu, P., and M. Ghildiyal. 2005. Potential targets for improving photosynthesis and crop yield. Current Science, 88: 19181928

32. Zadok's, J.C., T.T. Chang and C.F. Konzak .1974. A decimal code for the growth stages of cereals. Weed Res. 14: 415-421

33. Zeboon, N.H., S. A. Al. Hassan and H. A. Bager.2017. Response of two wheat varieties to irrigation blocking and ethephon foliar application. Alex. J. Agric. Sci. 61 (1) 111118. 